\title{
Demands made for inquiry into operations of reproductive health agency
}

A former federal health minister is calling for an independent inquiry into operations at the Assisted Human Reproduction Canada (AHRC) after three former board members testified at a parliamentary committee about the regulatory agency's financial irregularities, climate of intimidation and lack of transparency.

The federal government should appoint a neutral outsider to investigate what ARHC is doing with taxpayers' money, Liberal Health critic Ujjal Dosanjh told reporters Nov. 16, 2010, following a day of conflicting testimony before the House of Commons Standing Committee on Health.

Dosanjh, who called the agency an "ailing institution," said there are many unresolved issues surrounding the AHRC, despite testimony from the agency's chair and president that refuted former board members' allegations of fiscal mismanagement and secrecy. Several key directors of the board resigned earlier in 2010, while the agency's governing board said it could not fulfill its mandate (www.cmaj.ca/cgi/doi/10.1503 /cmaj.109-3295).

"You need someone of the stature of a judge to go into this and give us some answers and put this back on the track, so we have a well-functioning agency doing its work, not wasting money, and accountable to Canadians," says Dosanjh.

During the nearly three-hour meeting, Françoise Baylis, a bioethicist at Dalhousie University in Halifax, Nova Scotia, testified that she resigned after coming to the conclusion that the agency was failing to enforce, or was actively undermining, the principles of the Assisted Human Reproduction Act.

Baylis accused the board of "excessive, unnecessary secrecy that undermines the public trust." Along with former board members Barbara Slater and Irene Ryll, Baylis described difficulty getting line-item annual budgets, a lack of recorded votes, trouble getting the

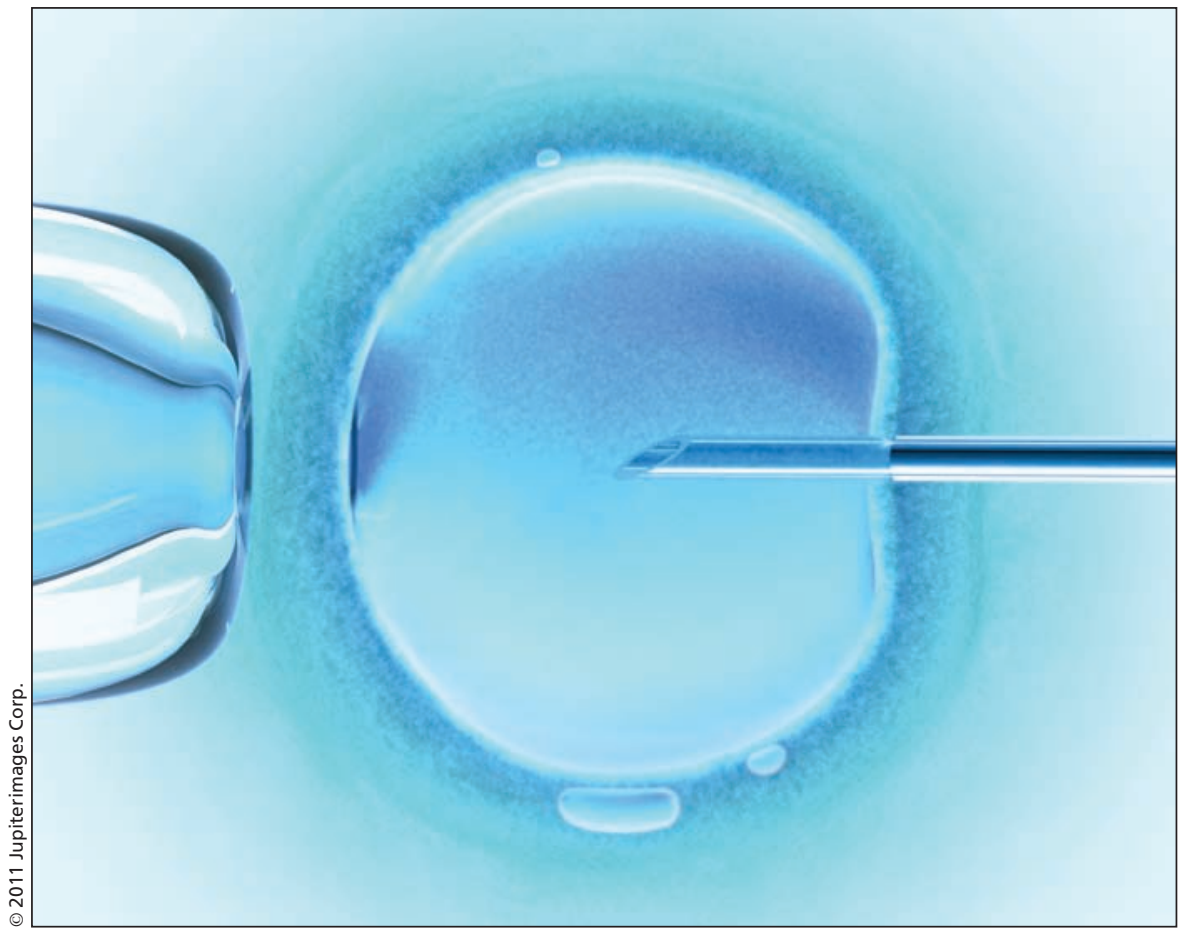

Canada's assisted human reproduction agency is "in limbo" and cannot regulate clinics and procedures because of a legal challenge, according to its chairman, Dr. John Hamm.

agency's president to reveal what percentage of the budget was being spent on board governance, and a refusal to post minutes on the website. The trio also said they couldn't discover the cost of an international conference the agency hosted, and that the board did not vote on the 2008-2009 budget.

They also described concerns over the more than $\$ 2$ million the agency allocated to consulting contracts in 2009-2010, while offering board members little information about the services to be provided.

Slater, a public policy expert, said such financial issues prompted her resignation, along with concerns that board members were being blocked from providing "substantive input" into the regulations that Health Canada is charged with drafting in order to implement sections of the Assisted Human Reproduction Act that are not yet in force.

"Requests for information about the budget consistently met with resistance from the president," Slater told the allparty committee.

Ryll, the only patient representative on the board, testified that she resigned because of "efforts to intimidate board members" about what they could and could not say publicly. She also believed the board was "broken and being managed by the president" and described "less than cordial" board meetings. That included "negative body language," eye-rolling and dismissive comments in response to board member questions, Ryll and Slater testified.

In stark contrast, AHRC Chair Dr. John Hamm, former premier of Nova Scotia, and President Elinor Wilson, a registered nurse, testified that the agency is functioning well, although it cannot meet several aspects of its mandate because of a legal challenge before the Supreme Court of Canada that is hampering its abilities to draft regulations. For example, it cannot yet license 
and regulate assisted reproduction clinics and procedures.

"We are in limbo," Hamm said.

Hamm testified that the agency has retained the accounting firm Price Waterhouse Coopers to audit its 20092010 financial statements because of the concerns raised about its finances. "I'm pleased to report that the preliminary document approved by Price Waterhouse Coopers has not raised any concerns."

The two remaining AHRC board members testified that they did not experience the same difficulties in obtaining information, or the disrespect their former colleagues described.
"I've received information in a timely manner," Theresa Kennedy testified. "If I've had questions about the materials, the president has been more than generous with her time."

Wilson flatly denied that she attempted to intimidate board members and described the conflicting opinions about the agency's operations as a matter of "perception."

AHRC has been mired in controversy almost since its inception, when Dosanjh - then Health Minister under former Prime Minister Paul Martin set up an expert panel to advise him about the board's composition. Applications were invited but in 2006, Prime
Minister Stephen Harper's Conservative government re-opened the selection process and handpicked some members of the board. Against the expert panel's advice, there were no patient representatives, stem cell researchers or obstetrician/gynecologists initially named.

Only after Baylis began questioning the lack of patient representatives was Ryll appointed to the board. There is no patient representative on the board now, since the government has not filled the seats of the three members who resigned. - Laura Eggertson, Ottawa, Ont.

CMAJ 2011.DOI:10.1503/cmaj.109-3741 